\title{
Birds of Lynn Lake, Manitoba
}

by Ronald R. Hooper, Punnichy, Saskatchewan

The following brief list of birds observed at or near the mining town of Lynn Lake, in northwestern Manitoba, is offered in the hope that it will provide some information toward a better understanding of the distribution of birds in the more remote parts of our provinces. Lynn Lake is approximately 140 miles north of Flin Flon and is about 40 miles east of the Saskatchewan border. The main trees in the area are black spruce, jack pine and white birch. This bird list is comprised of observations made by my brother, Donald Hooper, while working at Lynn Lake, from, June until October in 1956 and 1957, and by myself in the short period from January 2 to January 20, 1959. Unfortunately, my brother's records 'did not include exact dates and other details, hence it may be said for most species-merely that they were observed some time in the season of observation. Naturally, some of these would occur as migrants. The list includes 71 species. All records are for 1956 unless otherwise indicated.

Common Loon, Canada Goose, Mallard, Green-winged Teal, Redhead, Lesser Scaup, Common Goldeneye, Bufflehead, Hooded Merganser (one in fall, 1956), Common Merganser, Goshawk, Rough - legged Hawk, Golden Eagle, Bald Eagle, Marsh Hawk, Osprey (1957), Pigeon Hawk, Sparrow Hawk, Spruce Grouse (1956, one on Jan. 7 and Jan. 10, and two on Jan. 16, 1959), Sharp-tailed
Grouse, Sandhill Crane, Sora, Killdeer, Common Snipe, Spotted Sandpiper, Solitary Sandpiper, Greater Yellowlegs, Pectoral Sandpiper, Herring Gull, Mourning Dove (one, fall, 1957), Hawk-Owl (one, January 12, 1959), Short-eared Owl, Common Nighthawk (1956, and nest found), Yellow-shafted Flicker, Hairy Woodpecker, Black-backed Three-toed Woodpecker (1956, and one on January 16, 1959), Olive-sided Flycatcher, Horned Lark, Tree Swallow, Gray Jay (1956, and nearly every day from January 8 to January 20, 1959), Common Raven (1956, and nearly every day from January 2 to January 20, 1959), . Common Crow, Black-capped Chickadee (1956, also Jan. 12, Jan. 17 and Jan. 20, 1959), Boreal Chickadee (1956, also Jan. 5, Jan. 13 and Jan. 17, 1959), Robin, Hermit Thrush, Veery, Water Pipit, Northern Shrike, Orange-crowned Warbler (1956, nest found), Yellow Warbler (1957, nest found), Myrtle Warbler, House Sparrow, Red-winged Blackbird; Rusty Blackbird, Brewer's Blackbird, Common Grackle, Pine Grosbeak, Common Redpoll (1956, redpolls were heard on Jan. 12 and Jan. 17, 1959), Pine Siskin, Vesper Sparrow, Slate-colored Junco, Tree Sparrow, Chipping Sparrow, Whitecrowned Sparrow (1956, nest found), White-throated Sparrow, Fox Sparrow, Song Sparrow (1957, nest found), Swamp Sparrow, Lapland Longspur, Snow Bunting.

\section{CHRISTMAS BIRD COUNT}

Send in reports, listing the numbers of each species seen on the one BEST DAY between December 19 and January 1. In addition, list other species number of individuals and date seen) between December 19 and January 1.

Send reports as soon as possible to The Editor, Blue Jay, Box 1121, Regina.

\section{INFORMATION WANTED}

The Snowy Owl is an annual visitor from the North, being seen in many parts of the province. I am attempting to compile all available records in order to define the winter range of these birds in Saskatchewan. It would be appreciated if anyone sighting snowy Owls this winter would send their records to me.

B. C. Haysom,

750 Cameron Street, Regina, Saskatchewan 